\title{
Land use influences microbial biomass carbon, organic carbon and nitrogen stock in a tropical acric luvisols of Southwestern Nigeria
}

\section{Segun Oluwatomiwa Oladele ${ }^{1}$ and Adebayo Jonathan Adeyemo ${ }^{2}$}

${ }^{1}$ Adekunle Ajasin University Akungba Akoko. Faculty of Agriculture. Department of Agronomy. PMB 01, Akungba Akoko, Ondo State. Nigeria. Email: segun.oladele@aaua.edu.ng. ${ }^{2}$ Federal University of Technology. Department of Crop, Soil and Pest Management. Akure. Nigeria.

\begin{abstract}
A study was conducted to determine the effect of different land use on microbial biomass carbon, organic carbon and nitrogen stock on a tropical acric luvisols at Ibadan, Oyo State, Southwestern Nigeria. Soil samples were collected in 2014 using a quadrant approach across ten plots at the surface $(0-15 \mathrm{~cm})$ and sub-surface (16-30 cm) depths in four different land use systems of (i) 8-year old citrus, (ii) 8 year old cacao, (iii) 8 year oil palm and (iv) a fallow land of over 25 years. Significant differences in soil physical and chemical properties, microbial biomass carbon, carbon and nitrogen stock in different land use types at two depths $(0-15$ and $15-30 \mathrm{~cm})$ were observed on soil properties important for sustainable crop production. Fallow land use, oil palm plantation and cocoa plantation were characterized by higher carbon and nitrogen stock, microbial biomass carbon, total nitrogen, organic carbon, available phosphorus, marginally low exchangeable bases except for $\mathrm{Ca}$ and $\mathrm{Mg}$ with relatively higher values and marginal $\mathrm{C} / \mathrm{N}$ ratio. These land use also had lower bulk density, high total porosity, high moisture content and optimum soil temperature level. These results suggest that incorporation of optimum fallow cycle with appropriate land use in combination with soil enriching cover and tree crops in the study area will increase carbon and nitrogen stock while imitating a forest ecosystem condition which would help restore soil fertility in degraded lands while reducing greenhouse gas fluxes.
\end{abstract}

Keywords: Land use; Carbon; Nitrogen; Sequestration; Microbial biomass; Acric luvisols.
Received

September 20, 2016

Accepted

December 22, 2016

Released

December 31, 2016

Open Acess

Full Text Article

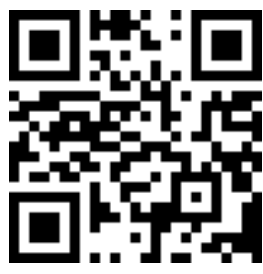

ORCID
0000-0002-7589-8658
Segun Oluwatomiwa
Oladele
0000-0002-7362-4143
Adebayo Jonathan
Adeyemo

\section{Introduction}

Soils are important sink of active carbon and play a major role in carbon sequestration, carbon and nitrogen cycle (Verena et al., 2010). Soil can also be an important source of atmospheric $\mathrm{CO}_{2}$ storage depending on land use, vegetation, soil cover and management practices (Lal, 2005). Anthropogenic induced influence on loss of soil organic matter from cultivated soil with profound over bearing effect on chemical, physical, and biological soil characteristics is now widely used as an indicator of soil degradation and quality. Forest soils are one of the major sequesters of carbon on earth due to their high organic matter status (Dixon et al., 1994).

The tree-crop agroforestry systems proffers an excellent opportunity in conserving soil organic matter while maintaining permanent soil cover, which 
stimulates faunal and microbial activity; produce more above and below ground litter and also increase the efficiency of soil exploration by root systems. Forest trees are known to bring about changes in edaphic, micro-climatic, flora, fauna and other components of the eco-system through biorecycling of mineral elements, temperature and moisture regime modifications and changes in flora and fauna composition among others (Attoe and Amalu, 2005; Ogunkunle and Awotoye, 2011). Furthermore, they also help to improve the nutrient balance of soil by reducing unproductive nutrient losses from erosion and leaching and by increasing nutrient inputs through nitrogen fixation and increase biological activities by providing biomass and suitable microclimate (Ogunkunle and Awotoye, 2011).

Nitrogen $(\mathrm{N})$ and organic carbon (OC) are the most complex and crucial of the macro elements essential for plant's life, and they play crucial roles in nutrient cycling, water, root growth, plant productivity, and environmental quality (Sainju et al., 2002). The proportions of OC and $\mathrm{N}$ in the soil are good indicators of soil quality and productivity due to their favourable effects on plants. Organic carbon influences many soil characteristics including colour, nutrient holding capacity, nutrient turnover and stability, which in turn influence water relations and aeration (Reddy et al., 2005). Nitrogen (N) is the macronutrient often limiting the growth of plants on soil, and soil total nitrogen (TN) has long been identified as a factor that is important to soil fertility in both managed and natural ecosystems (Kucharik et al., 2001). The concentration and availability of $\mathrm{N}$ in the soil directly influences plant productivity. Numerous field studies have shown that crop management practices can either enhanced or diminish quantities of soil OC and soil TN together (Bauer and Black, 1981; Potter et al., 1998; Knops and Tilman, 2000). It is also pertinent to note that soil organic carbon and nitrogen stock could be very sensitive to climate change, as a decline or loss from sinks could indicate increased level of global warming (Batjes, 1996). With this in hindsight, a periodic estimation of carbon and nitrogen pools in soils could help monitor changes in quality and losses of $\mathrm{CO}_{2}$ and nitrous oxides to the atmosphere.

Therefore, in order to provide sound effective soil fertility management strategies while mitigating carbon and nitrogen losses, a study was conducted in Ibadan, Southwestern Nigeria, to evaluate effect of differing land use type on soil carbon and nitrogen stock.

\section{Materials and methods}

\section{Study area}

This study area was within the premises of the Cacao Research Institute of Nigeria, Ibadan Oyo State, Southwest Nigeria. It is located in (Lat. $07^{\circ} 10^{\prime} \mathrm{N}$, Long. $03^{\circ} 52^{\prime} \mathrm{E}$, and $160 \mathrm{~m}$ above mean sea level). The tropical climate is marked with wet and dry seasons having a bimodal rainfall pattern with rainfall peaks between June to September (with an average annual of $2780 \mathrm{~mm}$ ), average relative humidity of about $(70 \%)$ and average annual maximum and minimum temperature is between $\left(22{ }^{\circ} \mathrm{C}\right.$ to $\left.36^{\circ} \mathrm{C}\right)$. The soil in the study area are sandy loam, brown loamy sand sub-soil well drained and formed with a slope of about 3\%. The dominant soil is the Iwo series, also known as Acric Luvisol (Smyth and Montgomery, 1962), which is also classified under the World Reference Base (WRB) as Kanhaplic Haplustalf.

\section{Sampling procedure}

A systematic sampling procedure was conducted with the aid of a soil auger from $5 \mathrm{~m} \mathrm{x} 5 \mathrm{~m}$ using a quadrant method across ten sampling plots at the surface $(0-15 \mathrm{~cm})$ and sub-surface $(15-30 \mathrm{~cm})$ depths in 2014 across different land use type dominated with different vegetation cover and undergrowth. The land use type were; (a) 8 year-old cacao plantation (b) 8 year-old oil palm plantation (c) 25-year-old fallow land (control) (d) 8 year-old citrus plantation. The soil micro climatic conditions, parent materials and topography all have similar characteristics which show that they are of the same origin. Forty-eight soils samples were collected and divided 
into equal halves stored in a hermetic bag, carefully labelled and transported to the laboratory, air-dried, crushed and sieved with $2 \mathrm{~mm}$ mesh sieve for physical, chemical and microbial biomass carbon analysis. The experiment was a Randomized Complete Block Design (RCBD); 4 (land use systems) at 2 (depth) factorial experiments with 3 replicates which sums up to 24 treatments in total.

\section{Soil physical properties analysis}

Soil bulk density was determined using the method described by Black and Hartge (1986), while the total porosity (\% pore space) was calculated using the same soil samples collected for soil bulk density. To determine the total porosity, the bulk density was divided by the particle size density (which is a constant of $2.65 \mathrm{~g} \mathrm{~cm}^{-3}$ ) and subtracted from one, and then the result was multiplied by 100 . These were done following the equations described by Suzuki et al. (2004). The soil moisture was determined using the samples collected for bulk density. The moisture content can be calculated based on a wet and dry basis (gravimetric method), but the dry basis was employed in this research. This was done by subtracting oven dry soil weight from the wet soil weight. The result was divided by the dry soil weight and then expressed in percentage.

\section{Soil chemical analysis}

The soil $\mathrm{pH}$ was determined by using 1:2 of $10 \mathrm{~g}$ of soil to $20 \mathrm{~mL}$ distilled water ratio suspension. The suspension was stirred for $30 \mathrm{~min}$ and determined by glass electrodes pHmeters which were standardized with a buffer of $\mathrm{pH} 7$. The organic matter was determined using Walkley-Black (1934) wet oxidation method. Potassium $\left(\mathrm{K}^{+}\right)$, Calcium $\left(\mathrm{Ca}^{2+}\right)$, Sodium $\left(\mathrm{Na}^{+}\right)$, and Magnesium $\left(\mathrm{Mg}^{2+}\right)$ were extracted by $1 \mathrm{M}$ ammonium acetate $\left(\mathrm{NH}_{4} \mathrm{OAC}\right)$, at $\mathrm{pH} 7$ and the extracts were determined on a flame photometer, while Calcium $\left(\mathrm{Ca}^{2+}\right)$ and Magnesium $\left(\mathrm{Mg}^{2+}\right)$ were determined by ethylene di-amine tetra acetic acid (EDTA) titration (AOAC, 1997).

\section{Determination of soil carbon and nitrogen stock}

Soil carbon stock and nitrogen stock was calculated using the formula adopted by Batjes (1996) as:

$$
\begin{aligned}
& \text { SCS }=\text { SOC } \times \text { BD } \times \text { area } \times \text { D } \\
& \text { SNC }=\text { TSN } \times \text { BD } \times \text { area } \times \text { D }
\end{aligned}
$$

Where:

$$
\begin{aligned}
& \text { SCS = Soil carbon stock }(\mathrm{Mg} / \mathrm{ha}) \\
& \text { SNC = soil nitrogen stock }(\mathrm{Mg} / \mathrm{ha}) \\
& \text { BD = bulk density }\left(\mathrm{g} / \mathrm{cm}^{3}\right) \\
& \text { SOC = Soil organic carbon }(\%) \\
& \text { TSN = total soil nitrogen }(\%) \\
& \text { D = soil depth }(\mathrm{cm})
\end{aligned}
$$

\section{Determination of microbial biomass carbon $\left(\mathrm{C}_{\text {mic }}\right)$ \\ Soil microbial biomass $\mathrm{C}$ was} estimated by extracting $25 \mathrm{~g}$ of oven dry equivalents from field-moist mineral soil samples in $0.5 \mathrm{M} \mathrm{K}_{2} \mathrm{SO}_{4}(1: 4 \mathrm{w} / \mathrm{v})$, known as the chloroform-fumigation-extraction method, described by Brookes et al. (1985) and Vance et al. (1987a). Microbial biomass $\mathrm{C}$ was calculated by measuring the difference in extractable organic $\mathrm{C}$ between the fumigated and unfumigated soils (Vance et al., 1987a):

$$
\text { Biomass } \mathrm{C}=2.64 \times \mathrm{EC}
$$

Where:

EC refers to the difference in extractable organic $\mathrm{C}$ between the fumigated and unfumigated treatments;

2.64 is the proportionality factor for biomass $\mathrm{C}$ released by fumigation extraction.

\section{analysis}

Data collection and statistical

Data collected were subjected to analysis of variance (ANOVA) using Statistical Analytical System (SAS) and the means were separated using Duncan's Multiple Range Test (DMRT) at $\mathrm{P}<0.05$ significant level. 


\section{Results and discussion}

Result from this study did indicate that land use types in the study area significantly $(\mathrm{P}<0.05)$ influenced soil physical properties (Table 1, 2, 3). Land use types based on the cropping system showed that bulk density was significantly $(\mathrm{P}<0.05)$ reduced and changes noticed when compared with other land use types under the fallow land and citrus plantation treatment with values of $\left(1.26 \mathrm{~g} / \mathrm{cm}^{3}\right.$ and $1.27 \mathrm{~g} / \mathrm{cm}^{3}$ ) recorded (Table 1 ), however values recorded in the other land use type were still below the ideal recommended bulk density weight of tropical soils according to Brady and Weil (2002).

Total porosity was significantly different $(\mathrm{P}<0.05)$ amongst the land use type, total porosity in soil analyzed from citrus plantation and fallow land were higher with values ranging from $52.05 \%-52.39 \%$ when compared with other land use types (Table 1).

Soil moisture content varied significantly $(\mathrm{P}<0.05)$ amongst the land use types, moisture content of citrus plantation soil was significantly lower (14.08\%) in comparison to fallow land and other land use type treatments.

Soil temperature across the land use types did not differ significantly, as values recorded were within close range and marginal. Interactive effect between land use types and soil depth showed significant $(\mathrm{P}<0.05)$ interactions and difference (Table 3).

At a depth of $0-15 \mathrm{~cm}$, fallow land and citrus plantations were significantly $(\mathrm{P}<0.05)$ different from fallow land and other land use type with lower values recorded $\left(1.15 \mathrm{~g} / \mathrm{cm}^{3}\right.$ and $\left.1.24 \mathrm{~g} / \mathrm{cm}^{3}\right)$, while at a depth of $16-30 \mathrm{~cm}$ down the soil profile, higher bulk density values were recorded. However, at this depth bulk density value for citrus plantation was significantly $(\mathrm{P}<0.05)$ lower $\left(1.30 \mathrm{~g} / \mathrm{cm}^{3}\right)$, when compared to fallow land and other land use type.

Total porosity was significantly $(\mathrm{P}<0.05)$ lower under oil palm plantation land use at soil depths of $0-15 \mathrm{~cm}$ and $16-30 \mathrm{~cm}$, respectively (Table 3). Soil moisture content from citrus plantation was significantly influenced by the land use and low in comparison with other land use types at depth of 0-15 cm and 16-30 cm.

From this study, land use types had no significant influence on soil temperature across soil depths of $0-30 \mathrm{~cm}$ as values recorded from treatments were marginal. The lower $(\mathrm{P}<0.05)$ bulk density as observed with fallow land and citrus plantation may be attributed to the improved soil organic matter from plant residue decomposition and improved soil structure. The different management system which influenced soil cover, organic matter, soil structure, and porosity across the land use types could also have dictated marginal differences in bulk density values.

This result is in agreement with the findings of Ovie et al. (2013) and Emadi et al. (2008) who reported that bulk density of surface soil was lowest in plantation soil compared to grassland vegetation because of enhanced soil organic matter. Furthermore, the increase in bulk density down the soil depth could be attributed to the fact that the soil subsurface layers have little or no organic matter accumulation, aggregation, and root penetration compared to surface layers and are predisposed to less pore space. Also the subsurface horizon being subjected to the weight of the surface layer above them may induce increased bulk density.

The higher total porosity values observed in citrus, cacao plantation and fallow land be attributed to the litter droppings and decomposing litters that could have enhanced soil microbial activities thereby stimulating the build-up and stabilization of soil structure, improved soil granulation and soil porosity. It is important to note that crops under the different land use type are perennial and their rooting system activity can also influence a more stable pore size distribution.

Findings from this study also agrees with that of Ovie et al. (2013) and Amama et al. (2013) who also observed that litter falls would increase soil organic matter (SOM) which has a correlation with improved soil structure and stability. The 
increased soil moisture content observed in cacao plantation and fallow land use type could be attributed to high organic matter content in these treatments. The favorable effect of SOM is most likely due to the moisture-holding capacity of the SOM and its beneficial influence on soil structure and soil porosity. Furthermore, reduce tillage and no-till practices could have increased total porosity, pore continuity and opened up pores at the surface layer which influenced water infiltration and percolation thereby increasing moisture content.
Recent studies have shown that considerable amounts of plant available nutrients and water can be present below the topsoil $(10-30 \mathrm{~cm})$ or even below $1 \mathrm{~m}$ depth, and that these resources may be used by plants. Numerous studies have also shown that soil moisture can be equal to or higher in the subsoil than in the topsoil. The ratio of subsoil-to-topsoil moisture varies greatly, but is generally higher with larger evaporation and with access to ground water (Borcher, 1994).

Table 1. Effects of land use types on soil physical properties at $0-15 \mathrm{~cm}$ depth.

\begin{tabular}{lcccc}
\hline Land use type & B. D. $\left(\mathbf{g} / \mathbf{c m}^{3}\right)$ & Total P (\%) & M. C. $(\%)$ & Temperature $\left({ }^{\circ} \mathbf{C}\right)$ \\
\hline Citrus & $1.27^{\mathrm{b}}$ & $52.05^{\mathrm{a}}$ & $14.08^{\mathrm{b}}$ & $30^{\mathrm{a}}$ \\
Cacao & $1.31^{\mathrm{a}}$ & $50.63^{\mathrm{b}}$ & $17.48^{\mathrm{a}}$ & $29^{\mathrm{a}}$ \\
Oil palm & $1.36^{\mathrm{a}}$ & $48.68^{\mathrm{b}}$ & $17.54^{\mathrm{a}}$ & $29^{\mathrm{a}}$ \\
Fallow land & $1.26^{\mathrm{b}}$ & $52.39^{\mathrm{a}}$ & $18.10^{\mathrm{a}}$ & $28^{\mathrm{a}}$ \\
\hline
\end{tabular}

Means with the same letters are not significantly different at $\mathrm{P}<0.05$, according to Duncan Multiple Range Test (DMRT).

Table 2. Effects of soil depth on soil physical properties.

\begin{tabular}{lcccc}
\hline Soil depth & B. D. $\left(\mathbf{g} / \mathbf{c m}^{3}\right)$ & Total P (\%) & M. C. $(\%)$ & Temperature $\left({ }^{\circ} \mathbf{C}\right)$ \\
\hline $0-15 \mathrm{~cm}$ & $1.27^{\mathrm{b}}$ & $52.1^{\mathrm{a}}$ & $16.67^{\mathrm{b}}$ & $30^{\mathrm{a}}$ \\
$16-30 \mathrm{~cm}$ & $1.36^{\mathrm{a}}$ & $48.7^{\mathrm{a}}$ & $18.23^{\mathrm{a}}$ & $28^{\mathrm{a}}$ \\
\hline
\end{tabular}

Means with the same letters in a column are not significantly different at $\mathrm{P}<0.05$ according to Duncan Multiple Range Test (DMRT); BD = Bulk density; M. C. = Moisture content; Total P =Total porosity.

Table 3. Interactive effect of soil depth and land use types on soil physical properties.

\begin{tabular}{llcccc}
\hline Soil depth & Land use type & B. D. $\left(\mathbf{g} / \mathbf{c m}^{\mathbf{3}}\right)$ & Total P (\%) & M. C. $(\mathbf{\%})$ & Temperature $\left(\mathbf{0}^{\mathbf{O}} \mathbf{C}\right)$ \\
\hline $\mathbf{0 - 1 5} \mathbf{~ c m}$ & Citrus & $1.24^{\mathrm{b}}$ & $53.18^{\mathrm{a}}$ & $14.33^{\mathrm{b}}$ & $31^{\mathrm{a}}$ \\
& Cacao & $1.29^{\mathrm{a}}$ & $51.30^{\mathrm{a}}$ & $18.15^{\mathrm{a}}$ & $30^{\mathrm{a}}$ \\
& Oil palm & $1.36^{\mathrm{a}}$ & $48.87^{\mathrm{b}}$ & $16.84^{\mathrm{a}}$ & $30^{\mathrm{a}}$ \\
& Fallow land & $1.15^{\mathrm{b}}$ & $56.71^{\mathrm{a}}$ & $17.15^{\mathrm{a}}$ & $29^{\mathrm{a}}$ \\
\hline $\mathbf{1 6 - 3 0} \mathbf{~ c m}$ & Citrus & $1.30^{\mathrm{b}}$ & $50.91^{\mathrm{a}}$ & $16.83^{\mathrm{b}}$ & $29^{\mathrm{a}}$ \\
& Cacao & $1.33^{\mathrm{a}}$ & $49.97^{\mathrm{a}}$ & $20.81^{\mathrm{a}}$ & $28^{\mathrm{a}}$ \\
& Oil palm & $1.37^{\mathrm{a}}$ & $47.49^{\mathrm{b}}$ & $18.23^{\mathrm{a}}$ & $27^{\mathrm{a}}$ \\
& Fallow land & $1.38^{\mathrm{a}}$ & $48.06^{\mathrm{a}}$ & $19.05^{\mathrm{a}}$ & $27^{\mathrm{a}}$ \\
\hline
\end{tabular}

Means with the same letters in a column are not significantly different at $\mathrm{P}<0.05$, according to Duncan Multiple Range Test (DMRT); B. D. = Bulk density; M. C. = Moisture content; Total P = Total porosity. 
The effects of land use type on soil chemical properties are presented in Table 4, 5, and 6. Results showed that land use type did not significantly $(\mathrm{P}<0.05)$ influence soil $\mathrm{pH}$ at soil depth of $0-15 \mathrm{~cm}$, however fallow land had a high $\mathrm{pH}$ range (6.0) amongst the treatments and was slightly acidic. N, P, K, Na, Mg, organic carbon and $\mathrm{C}: \mathrm{N}$ ratio were not significantly $(\mathrm{P}<0.05)$ affected by land use types at soil depth of $0-15 \mathrm{~cm}$ (Table 4). However, Ca was significantly $(\mathrm{P}<0.05)$ influenced by land use type as the fallow land treatment recorded a higher value $(9.40 \mathrm{cmol} / \mathrm{kg})$ in comparison with other land use type. Interaction between land use types and soil depth show that no significant $(\mathrm{P}<0.05)$ interaction was observed in all soil chemical properties assayed $(\mathrm{N}, \mathrm{P}, \mathrm{K}, \mathrm{Mg}$, $\mathrm{Na}$, O.C and C:N ratio) at a depth of $0-15 \mathrm{~cm}$ except for $\mathrm{Ca}$, where the fallow land use type was significantly high in calcium (Table 5). Furthermore, soil nitrogen content decreased down the soil depth following this trend: $(0-15 \mathrm{~cm}>$ $16-30 \mathrm{~cm})$ across the land use types, inversely, available phosphorus levels increased down the soil depth across all land use type. Exchangeable $\mathrm{K}$ was not significantly $(\mathrm{P}<0.05)$ influenced by land use type, however oil palm treatment and fallow land experienced a slight decrease in $\mathrm{K}$ values down the soil depth $(16-30 \mathrm{~cm})$ (Table 6). Other exchangeable bases such as $(\mathrm{Ca}, \mathrm{Mg}$, and $\mathrm{Na}$ ) were significantly influenced by land use type albeit at (16-30 cm) depth where an increase in this bases was observed in all land use types, fallow land treatment was observed to have recorded the highest value of exchangeable bases at $30 \mathrm{~cm}$ soil depth amongst the land use types. Land use type had no significant $(\mathrm{P}<0.05)$ effect on soil organic carbon and C:N ratio at a depth of $15 \mathrm{~cm}$, however oil palm and fallow land treatment recorded higher values of $(1.49 \%$ and $1.36 \%)$ and (7.84 and 6.80), respectively. However, a decreasing trend in SOC levels was observed at soil depth of $30 \mathrm{~cm}$ across all land use types while an increasing trend in $\mathrm{C}: \mathrm{N}$ ratio was observed at the same depth across all land use types except for fallow land where a decrease was measured (Table $6)$.

Table 4. Effects of land use types on soil chemical properties at $0-15 \mathrm{~cm}$ soil depth.

\begin{tabular}{lccccccccc}
\hline Land use types & $\mathbf{p H}$ & $\mathbf{N}$ & $\mathbf{P}$ & $\mathbf{K}$ & $\mathbf{N a}$ & $\begin{array}{c}\text { Ca } \\
\mathbf{c m o l} / \mathbf{k g}\end{array}$ & $\mathbf{M g}$ & $\mathbf{O . ~ C . ~}$ & $\begin{array}{c}\mathbf{C}: \mathbf{N} \\
\mathbf{( \% )}\end{array}$ \\
\hline Citrus & $5.8^{\mathrm{a}}$ & $0.17^{\mathrm{a}}$ & $8.02^{\mathrm{a}}$ & $0.32^{\mathrm{a}}$ & $0.22^{\mathrm{a}}$ & $5.40^{\mathrm{ab}}$ & $2.35^{\mathrm{a}}$ & $0.77^{\mathrm{a}}$ & $4.53^{\mathrm{a}}$ \\
Cacao & $5.2^{\mathrm{a}}$ & $0.13^{\mathrm{a}}$ & $9.10^{\mathrm{a}}$ & $0.31^{\mathrm{a}}$ & $0.26^{\mathrm{a}}$ & $2.20^{\mathrm{b}}$ & $1.25^{\mathrm{a}}$ & $0.83^{\mathrm{a}}$ & $6.38^{\mathrm{a}}$ \\
Oil palm & $5.6^{\mathrm{a}}$ & $0.17^{\mathrm{a}}$ & $8.92^{\mathrm{a}}$ & $0.30^{\mathrm{a}}$ & $0.24^{\mathrm{a}}$ & $2.51^{\mathrm{ab}}$ & $2.15^{\mathrm{a}}$ & $1.46^{\mathrm{a}}$ & $5.59^{\mathrm{a}}$ \\
Fallow land & $6.0^{\mathrm{a}}$ & $0.18^{\mathrm{a}}$ & $7.14^{\mathrm{a}}$ & $0.29^{\mathrm{a}}$ & $0.38^{\mathrm{a}}$ & $9.40^{\mathrm{a}}$ & $4.33^{\mathrm{a}}$ & $1.31^{\mathrm{a}}$ & $7.28^{\mathrm{a}}$ \\
\hline
\end{tabular}

Means with the same letters in a column are not significantly different at $\mathrm{P}<0.05$ according to Duncan Multiple Range Test (DMRT).

Table 5. Effects of soil depth on soil chemical properties.

\begin{tabular}{lccccccccc}
\hline Soil depth & $\mathbf{p H}$ & $\mathbf{N}$ & $\mathbf{P}$ & $\mathbf{K}$ & $\mathbf{N a}$ & $\begin{array}{c}\mathbf{C a} \\
\mathbf{c m o l} / \mathbf{k g}\end{array}$ & $\mathbf{M g}$ & $\mathbf{O} . \mathbf{C}$. & $\begin{array}{c}\mathbf{C}: \mathbf{N} \\
(\mathbf{\%})\end{array}$ \\
\hline $\mathbf{0 - 1 5} \mathbf{~ c m}$ & $5.5^{\mathrm{a}}$ & $0.19^{\mathrm{a}}$ & $8.24^{\mathrm{a}}$ & $0.36^{\mathrm{a}}$ & $0.31^{\mathrm{a}}$ & $4.81^{\mathrm{b}}$ & $2.56^{\mathrm{a}}$ & $1.15^{\mathrm{a}}$ & $6.1^{\mathrm{a}}$ \\
$\mathbf{1 6 - 3 0 ~ \mathbf { ~ c m }}$ & $6.0^{\mathrm{a}}$ & $0.15^{\mathrm{a}}$ & $9.01^{\mathrm{a}}$ & $0.28^{\mathrm{a}}$ & $0.28^{\mathrm{a}}$ & $5.52^{\mathrm{a}}$ & $3.23^{\mathrm{a}}$ & $0.91^{\mathrm{a}}$ & $6.0^{\mathrm{a}}$ \\
\hline
\end{tabular}

Means with the same letters in a column are not significantly different at $\mathrm{P}<0.05$ according to Duncan Multiple Range Test (DMRT). 
Table 6. Interactive effect of land use types and soil depth on soil chemical properties.

\begin{tabular}{|c|c|c|c|c|c|c|c|c|c|c|}
\hline Soil depth & $\begin{array}{c}\text { Land use } \\
\text { types }\end{array}$ & pH & $\mathbf{N}$ & $\mathbf{P}$ & $\mathbf{K}$ & $\mathrm{Na}$ & Ca & Mg & O. C. & $\begin{array}{l}\text { C:N } \\
(\%)\end{array}$ \\
\hline \multirow[t]{4}{*}{$0-15 \mathrm{~cm}$} & Citrus & $5.6^{\mathrm{a}}$ & $0.18^{\mathrm{a}}$ & $8.02^{\mathrm{a}}$ & $0.36^{\mathrm{a}}$ & $0.25^{\mathrm{a}}$ & $5.10^{\mathrm{ab}}$ & $2.31^{\mathrm{a}}$ & $0.79^{\mathrm{a}}$ & $4.38^{\mathrm{a}}$ \\
\hline & Cacao & $5.0^{\mathrm{a}}$ & $0.15^{\mathrm{a}}$ & $8.80^{\mathrm{a}}$ & $0.35^{\mathrm{a}}$ & $0.29^{\mathrm{a}}$ & $2.30^{\mathrm{b}}$ & $1.27^{\mathrm{a}}$ & $0.88^{\mathrm{a}}$ & $5.87^{\mathrm{a}}$ \\
\hline & Oil palm & $5.3^{\mathrm{a}}$ & $0.19^{\mathrm{a}}$ & $8.72^{\mathrm{a}}$ & $0.33^{\mathrm{a}}$ & $0.26^{\mathrm{a}}$ & $2.71^{\mathrm{ab}}$ & $2.17^{\mathrm{a}}$ & $1.49^{\mathrm{a}}$ & $7.84^{\mathrm{a}}$ \\
\hline & Fallow land & $5.8^{\mathrm{a}}$ & $0.20^{\mathrm{a}}$ & $7.04^{\mathrm{a}}$ & $0.34^{\mathrm{a}}$ & $0.39^{\mathrm{a}}$ & $9.37^{\mathrm{a}}$ & $4.31^{\mathrm{a}}$ & $1.36^{\mathrm{a}}$ & $6.80^{\mathrm{a}}$ \\
\hline \multirow[t]{4}{*}{$16-30 \mathrm{~cm}$} & Citrus & $5.9^{\mathrm{a}}$ & $0.15^{\mathrm{a}}$ & $8.92^{\mathrm{a}}$ & $0.35^{\mathrm{a}}$ & $0.22^{b}$ & $6.42^{\mathrm{a}}$ & $2.66^{\mathrm{b}}$ & $0.68^{\mathrm{a}}$ & $4.53^{\mathrm{b}}$ \\
\hline & Cacao & $5.8^{\mathrm{a}}$ & $0.12^{\mathrm{a}}$ & $9.07^{\mathrm{a}}$ & $0.35^{\mathrm{a}}$ & $0.27^{\mathrm{b}}$ & $3.46^{b}$ & $2.02^{\mathrm{b}}$ & $0.73^{\mathrm{a}}$ & $6.08^{\mathrm{a}}$ \\
\hline & Oil palm & $5.6^{\mathrm{a}}$ & $0.14^{\mathrm{a}}$ & $9.01^{\mathrm{a}}$ & $0.32^{\mathrm{a}}$ & $0.26^{\mathrm{b}}$ & $2.85^{\mathrm{b}}$ & $2.67^{b}$ & $1.12^{\mathrm{a}}$ & $8.00^{\mathrm{a}}$ \\
\hline & Fallow land & $6.0^{\mathrm{a}}$ & $0.16^{\mathrm{a}}$ & $8.82^{\mathrm{a}}$ & $0.31^{\mathrm{a}}$ & $0.39^{\mathrm{a}}$ & $9.22^{\mathrm{a}}$ & $4.92^{\mathrm{a}}$ & $1.02^{\mathrm{a}}$ & $6.38^{\mathrm{a}}$ \\
\hline
\end{tabular}

Means with the same letters in a column are not significantly different at $\mathrm{P}<0.05$ according to Duncan Multiple Range Test

The increased $\mathrm{pH}$ value of fallow land use type in relation to other land use types indicate the presence of a thick layer of cover over the soil surface, reduced erosion and gradual decomposition of covers which helped increase the soil pH. It was noticed other land use types had similar $\mathrm{pH}$ range which indicates occurrence of similar chemical reactions taking place on these soils. Furthermore, the tree crop architecture on these land use types, could have allowed for interplant row spacing which have no soil cover and would make rainfall impact be felt and soil surface layer prone to erosion and leaching. Old tree crops in a plantation system are known for their acidic condition with $\mathrm{pH}$ range of 4.5-5.5 (Owaiye, 1989). This is due to the build-up of exudates from the root of these crops in the rhizosphere which makes the soil acidic. Accumulation of these exudates in the soil over the years makes the need for soil amendment essential to increase the soil $\mathrm{pH}$ and buffering capacity. The total soil nitrogen content at the surface level of the various land use types in this study were above the critical levels $0.10 \mathrm{~g} / \mathrm{kg}$ which is required for the various tree cropping system. The high nitrogen level at the subsurface level across the land use type also indicates increased leaching of nitrogen down the soil sub-surface horizon. This could be attributed to the continuous use of inorganic nitrogenous fertilizers; the low total $\mathrm{N}$ especially across the soil depths in the soil collected in cacao plantation could also be attributed leaching losses of the mobile nitrate ion $\left(\mathrm{NO}_{3}-\mathrm{N}^{+}\right)$. Available $\mathrm{P}$ was highest in cacao and oil palm land use at the surface and sub-surface soil depths, this could be attributed to the long-term phosphorus fertilization under this land use type and the associated increase in microbial activity. Materechera and Mkhabela (2001) reported that soil OM does influence $\mathrm{P}$ in soil solution by complexing $\mathrm{P}$ from adsorption site in ligand exchange and increasing the mobility of inorganic P, particularly in acid soils, by decreasing chemical activity of iron and aluminum (Kiflu and Beyene, 2013). Furthermore, mineralization of organic $\mathrm{P}$ to available P, litter falls and crop residue under these land use type crop may have coated the reaction surfaces of the soil particles and hindered $\mathrm{P}$ sorption, thereby increasing $\mathrm{P}$ solubility. Exchangeable bases; potassium $(\mathrm{K})$ and $(\mathrm{Na})$ across the land use were generally low across surface and sub-surface pedons with a decreasing trend of citrus $>$ cacao $>$ fallow land $>$ oil palm and fallow land $>$ cacao $>$ oil palm $>$ citrus, respectively.

Low exchangeable $\mathrm{K}$ at the surface and sub-surface layers across the land use could be due to the removal of crop residues and litter falls, by rainfall run-off, minimal inorganic and organic phosphorus fertilization. This result is support previous findings that indicate intensive weathering, cultivation and use of acid forming inorganic fertilizers affect the distribution 
of $\mathrm{K}$ in the soil system and enhance its depletion (Malo et al., 2005; Kiflu and Beyene, 2013). Exchangeable $\mathrm{Ca}$ and $\mathrm{Mg}$ was marginally low across the land use types at the surface pedon, however fallow land and citrus land use were the highest respectively while fallow land was the highest at sub-surface pedon. The exchangeable bases (Ca, Mg) were found to be a bit high at sub-surface pedon for fallow land use alone and this could be due to leaching of bases at surface pedon and accumulation at sub-surface pedon, runoff and soil erosion. These losses could also be induced by the effects of parent materials, land form, vegetation and climatic patterns in tropical regions where excessive rainfall coupled with unfavourable temperature and precipitation is high enough to leach appreciable amounts of exchangeable basic ions like calcium $(\mathrm{Ca})$, magnesium $(\mathrm{Mg})$, sodium $(\mathrm{Na})$ and potassium $(\mathrm{K})$ from the surface of soil. Fallow land and oil palm land use recorded relatively high organic carbon content across the soil depths. This could be attributed to the lack of continuous cultivation which exacerbates organic matter oxidation. The accumulation of roots, leaves, twigs, grasses and fungal hyphae could probably be responsible for the higher amount of total organic matter.
$\mathrm{C} / \mathrm{N}$ ratio was low across the land use and at surface and sub-surface pedon, this is advantageous and could be attributed to the decomposition rates of residues, mineralization of litters which increased accumulation of humus thereby increasing soil fertility. $\mathrm{C} / \mathrm{N}$ ratio is an important indices indicating plant residue quality because $\mathrm{C} / \mathrm{N}$ ratio determines the pattern and rate of residue decomposition (Brady and Weil, 2002).

Management practices and land use were observed to exert a profound influence on carbon and nitrogen stock (Table 7). At the surface and sub-surface pedon, oil palm and fallow land use recorded the highest carbon and nitrogen stock. This significant $(\mathrm{P}>0.05)$ high stock rate relative to other land use could be attributed to higher level of organic matter, increased bulk density which reduced water infiltration, soil aeration, soil biodiversity and decomposition rates of organic material. Research findings have shown that conversion of forest land into cultivation requires addition of organic inputs otherwise it could exacerbate global warming by reducing the amount of soil carbon stock (Chen and $\mathrm{Xu}, 2010$ ).

Table 7. Effect of land use types on soil carbon and nitrogen stock.

\begin{tabular}{llcc}
\hline Soil depth & Land use type & Carbon $\left.\mathbf{( m g ~ C}^{\mathbf{C}} \mathbf{h a}^{-\mathbf{1}}\right)$ & Nitrogen $\mathbf{( m g ~ N ~ h a}^{\mathbf{1}}$ ) \\
\hline $0-15 \mathrm{~cm}$ & Citrus & $1,469 \mathrm{c}$ & $334.8 \mathrm{a}$ \\
& Cacao & $1,703 \mathrm{c}$ & $290.0 \mathrm{~b}$ \\
& Oil palm & $3,039 \mathrm{a}$ & $388.0 \mathrm{a}$ \\
& Fallow land & $2,346 \mathrm{~b}$ & $345.0 \mathrm{a}$ \\
\hline $16-30 \mathrm{~cm}$ & Citrus & $2,652 \mathrm{~b}$ & $585.0 \mathrm{~b}$ \\
& Cacao & $2,913 \mathrm{~b}$ & $479.0 \mathrm{c}$ \\
& Oil palm & $4,603 \mathrm{a}$ & $575.0 \mathrm{~b}$ \\
& Fallow land & $4,223 \mathrm{a}$ & $662.0 \mathrm{a}$ \\
\hline
\end{tabular}

Means with the same letters in a column are not significantly different at $\mathrm{P}<0.05$, according to Duncan Multiple Range Test (DMRT).

Studies have shown relationships between soil carbon stock and soil nitrogen stock with soil physicochemical properties (Onwudike et al., 2016). There exist a significant positive correlation between soil carbon stock with organic carbon content, exchangeable bases (Mg), total nitrogen and soil $\mathrm{pH}$ while soil nitrogen stock is 
correlated positively with organic carbon, total nitrogen and soil $\mathrm{pH}$ (Onwudike et al., 2016). Therefore, increase in soil $\mathrm{pH}$, microbial activity and mineralization of organic matter would conversely increase soil carbon stock and nitrogen stock. Haney et al. (2004) also posited that soil moisture retention could also influence the level of $\mathrm{CO}_{2}$ fluxes in the soil which influences soil microbial biomass and potential carbon and nitrogen stock.

Table 8 shows the effect of land use and soil depth on soil microbial biomass carbon. Although no significant difference was observed across the land use types at both surface and sub-surface soil depth, fallow and oil palm land use recorded higher values of microbial biomass carbon $\left(251 \mathrm{C}_{\text {mic }} \mathrm{mg} / \mathrm{kg}\right.$ and $\left.219 \mathrm{C}_{\text {mic }} \mathrm{mg} / \mathrm{kg}\right)$ at surface pedon and $\left(188 \mathrm{C}_{\text {mic }} \mathrm{mg} / \mathrm{kg}\right.$ and $144 \mathrm{C}_{\text {mic }} \mathrm{mg} / \mathrm{kg}$ ) at sub-surface pedon respectively. Values obtained at sub-surface pedon; 16-30 cm were lower compared to the values obtained between 0-15 cm depths. High microbial biomass usually indicate an increased repository in the organic fraction, and could serve as sink or a source of plant-available nutrients, depending on the soil management practices. The relatively dense structure of tree crops and accumulation of litters and fine roots in the under-storey of oil palm and grasses/pasture in the fallow land may have influenced the growth of microbial populations and the accumulation of carbon in microbial biomass. Soil microbial biomass carbon is an important pool of plant nutrients and is often highly correlated with the organic matter content of soils. Furthermore, the clay content of soil could also play a role in determining microbial biomass and activity as well as influencing the composition of microbial community (McCulley and Burke, 2004). Soils with high clay content lead to more stabilization of soil organic $\mathrm{C}$ and higher microbial biomass (Schimel et al., 1994).

Table 8. Effect of Land use and Soil depth on the Soil microbial biomass carbon.

\begin{tabular}{llc}
\hline Soil depth & Land use & Value $\left(\mathbf{C}_{\mathbf{m i c}} \mathbf{~} \mathbf{g} / \mathbf{k g}^{-\mathbf{1}}\right)$ \\
\hline $0-15 \mathrm{~cm}$ & Citrus & $218 \mathrm{a}$ \\
& Cacao & $206 \mathrm{a}$ \\
& Oil palm & $219 \mathrm{a}$ \\
& Fallow land & $251 \mathrm{a}$ \\
\hline $16-30 \mathrm{~cm}$ & Citrus & $128 \mathrm{a}$ \\
& Cacao & $117 \mathrm{a}$ \\
& Oil palm & $147 \mathrm{a}$ \\
& Fallow land & $188 \mathrm{a}$ \\
\hline
\end{tabular}

Means with the same letters in a column are not significantly different at $\mathrm{P}<0.05$, according to Duncan Multiple Range Test (DMRT).

\section{Conclusion}

In southwestern region of Nigeria, where more intensive land use have resulted in degradation of soil quality due to continuous cropping, run-off, erosion and removal of soil covers. Characterizing spatial variability of soil nutrients vis-à-vis land use, soil carbon and nitrogen stock and other associated soil chemical/microbial properties are important in understanding ecosystem functions and assessing the effects of further land use change on soil health. Findings of this study suggest that many soil properties are influenced by land use. Soils from continuously cultivated land with minimal vegetation cover is often characterized by low carbon and nitrogen stocks and poor physical condition. However from this study, increased carbon and nitrogen stock in the fallow, oil palm and cacao plantation shows that the land 
use system could imitate forest ecosystem conditions with profound influence on nutrient accumulation in the soil due to the dense canopy architecture which helps in minimizing nutrient loss through soil erosion and leaching. Furthermore, litter falls also provided conducive habitat for microbial activity which facilitates organic matter decomposition, thereby increasing carbon and nitrogen sequestration in the soil. Therefore, it is essential that the incorporation of optimum fallow cycle with appropriate land use in combination with soil enriching cover and tree crops in the study area would help restore soil fertility in degraded lands while maintaining nutrient for continuous energy fluxes.

\section{Acknowledgement}

The research team is grateful to laboratory technologists in the Department of Crop soil and pest management, Federal University of Technology Akure, for their assistance with soil analysis and laboratory work.

\section{Conflicts of interest}

Authors declare that they have no conflict of interests.

\section{References}

Amana, A. M., Jayeoba, O. J.; Agbede, O. O. Effects of land use types on soil quality in Southern Guinea Savannah, Nasarawa State of Nigeria. Nig. J. of Soil Sci., v. 22, no. 1, p. 2131, 2012.

AOAC - Association of Official Analytical Chemists International. Official Methods of Analysis of the Association of Official Analytical Chemists International. 16 ed. Arligton: AOAC, 1997.

Attoe, E. E.; Amalu, U. C. Evaluation of phosphorus status of some soils under estate rubber (Hevea brasiliensis Muel. Argo. [sic]) trees in Southern Cross River State. Global J. Agric. Sci., v. 4, no. 1, p. 55-61, 2005.

Bauer, A.; Black, A. L. Soil carbon, nitrogen and bulk density comparisons in two cropland tillage systems after 25 years and in virgin grassland. Soil Sci. Soc. Am. J., v. 45, p. 11661170, 1981.
Batjes, N. H. Total carbon and nitrogen in the soil of the world. European Journal of Soil Science, v. 47, p. 151-163, 1996.

Black, G. R.; Hartge, K. H. Bulk density. In: Klute, A. (Ed.). Methods of soil analysis. Part I. Physical and mineralogical methods. 2. ed. Madison, Wisconsin: ASA-SSSA., 1986. p. 363-375. (Agronomy no. 9).

Borcher R. Soil and stem water storage determine phenology and distribution of tropical dry forest trees. Ecology, v. 75, no. 5, p. 14371449, 1994.

Brady, N.; Weil, R. The nature and properties of soils. 13 ed. Upper Saddle River, New Jersey: Prentice Hall, 2002.

Brookes, P. C.; Landman, A.; Pruden, G.; Jenkinson, D. S. Chloroform fumigation and the release of soil nitrogen: a rapid direct extraction method to measure microbial biomass nitrogen in soil. Soil Biol. Biochem., v. 17, p. 837-842, 1985.

Chen C.; Xu, Z. Forest ecosystem responses to environmental changes: The key regulatory role of biogeochemical cycling. Journal of Soils Sediments, v. 10, p. 210-214, 2010.

Dixon, R. K.; Brown, S.; Houghton R. A.; Solomon, A. M.; Trexler, M. C.; Wisniewski, J. Carbon pools and flux of global forest ecosystems. Science, v. 263, p. 185-190, 1994. https://dx.doi.org/10.1126/science.263.5144.185

Emadi, M.; Emadi, M.; Bagherjenad, M.; Fathi, H.; Saffari, M. Effect of land use change on selected soil physical and chemical properties in North Highland of Iran. Iranian Journal of Agriculture, v. 8, p. 496-502, 2008.

Haney, R. L.;Franzluebbers, A. J.; Porter, E. B.; Hons, F. M.; Zuberer, D A. Soil carbon and nitrogen mineralization. Soil Sci. Soc. of Am. J., v. 68, p. 489-492, 2004. Available from: $<$ https://naldc.nal.usda.gov/naldc/download.xht ml?id=9449\&content=PDF $>$. Accessed on: Jun. 23, 2016.

Kiflu, A.; Beyene S. Effects of different land use systems on selected soil properties in South Ethiopia. J. Soil Sci. and Envr. Mgt., v. 4, no. 5, p. 100-107, 2013. https://dx.doi.org/10.5897/JSSEM12.20

Knops, J. M. H.; Tilman, D. Dynamics of soil nitrogen and carbon accumulation for 61 years after agricultural abandonment. Ecology, v. 81, p. 88-98, 2000.

Kucharik, C. J.; Brye, K. R.; Norman, J. M.; Foley, J. A.; Gower, S. T.; Bundy, L. G. Measurements and modeling of carbon and nitrogen cycling in agroecosystems of southern 
Wisconsin: potential for SOC sequestration during the next 50 years. Ecosystems, v. 4, p. 237-258, 2001.

Lal, R. No-till farming and environment quality. Anais do Simpósio sobre Plantio Direto e Meio Ambiente: Sequestro de Carbono e Qualidade da Água, Foz do Iguaçu, p. 29-37, 2005.

McCulley, R. L.; Burke, I. C. Microbial community composition across the Great Plains: landscape versus regional variability. Soil Sci. Soc. Am. J., v. 68, p. 106-115, 2004.

Malo, D. D.; Schumacher, T. E.; Doolittle, J. J. Long-term cultivation impacts on selected soil properties in the Northern Great Plains. Soil Tillage Res., v. 81, p. 277-291, 2005.

Materechera, S. A.; Mkhabela, T. S. Influence of land-use on properties of a ferralitic soil under low external input farming in Southern Swaziland. Soil Tillage Res., v. 62, p. 15-25, 2001.

Ogunkunle, C. O.; Awotoye, O. O. Soil fertility under different tree cropping system in a Southwestern zone of Nigeria. Not. Sci. Biol., v. 3, p. 123-128, 2011.

Onwudike, S. U.; Uzoho, B. U.; Ndukwu, B. N.; Opara, I. U.; Anyamale, O. C. Soil carbon and nitrogen stock as affected by agricultural wastes in a typic haplusult of Owerri Southeastern Nigeria. Turkish Journal of Agriculture Food Science and Technology, v. 4, no. 7, p. 592-599, 2016.

Ovie, S.; Obande, A. O.; Ataga, E. Effects of land uses on the properties of soils formed on Makurdi sandstones in North Central Nigeria. Nig. J. of Agric., Food and Env., v. 9, no. 4, p. 43-47, 2013.

Owaiye, A. R. Effects of soil acidity on germination, growth and performance of cashew. Cocoa Research Institute of Nigeria (CRIN), 1989. P. 49-52, (Annual report).

Potter K. N.; Torbert, H.A.; Jones, O. R.; Matocha, J. E.; Morrison, J. E. J.; Unger, P.W. Distribution and amount of soil organic $C$ in long-term management systems in Texas. Soil Tillage Res., v. 47, p. 309-321, 1998.
Reddy, K. R.; Wetzel, R. G.; Kadlec, R. H. Biogeochemistry of phosphorus in wetlands. In: Sims, J. T.; Sharpley, A. N. (Eds). Phosphorus: agriculture and the environment. Madison: ASA, CSSA, and SSSA, 2005. p. 263-316. (Agron. Monogr., 46).

Sainju, U. M.; Singh, B. P.; Whitehead, W. F. Long term effects of tillage, cover crops and nitrogen fertilization on organic carbon and nitrogen concentrations in sandy loam soils in Georgia, USA. Soil and Tillage Res., v. 63, no. 3, p. 167-179, 2002.

Schimel, D. S.; Braswell, B. H.; Holland, E. A.; McKeown, R.; Ojima, D. S.; Painter, T. T.; Parton, W. J.; Townsend, A. R. Climatic, edaphic, and biotic controls over storage and turnover of carbon in soils. Global Biogeochem Cy., v. 8, p. 279-293, 1994.

Smyth, A. J.; Montgomery, R. F. Soil and land use in central Western Nigeria. Ibadan, Western Nigeria: Govt. Printer, 1962.

Suzuki, L. E. A. S.; Ranert, D. J.; Reichert, J. M. Degree of compactness for no-tillage soils: reference bulk density and effects on soil physical properties and soybean yield. 2004. Available from: <http://www.fisicadosolo. ccr.ufsm.quoos.com.br/downloads/Producao_Re sumos/17ISTRO_3.pdf>. Accessed on: Jun. 23, 2016.

Vance, E. D.; Brookes, P. C.; Jenkinson, D. S. An extraction method for measuring soil microbial C. Soil Biol. Biochem., 19: 703-707, 1987.

Verena, D.; Peter, F.; Karl, S. Layer specific analysis and spatial prediction of soil organic carbon using terrain attributes and erosion modelling. Soil Sci. Soc. Am. J., v. 74, p. 922935, 2010.

Walkey, A.; Black, I. A. An examination of Degtjareff Method for determining soil organic matter and proposed modification of chromic acid titration method. Soil Science, v. 37, p. 2937, 1934. 